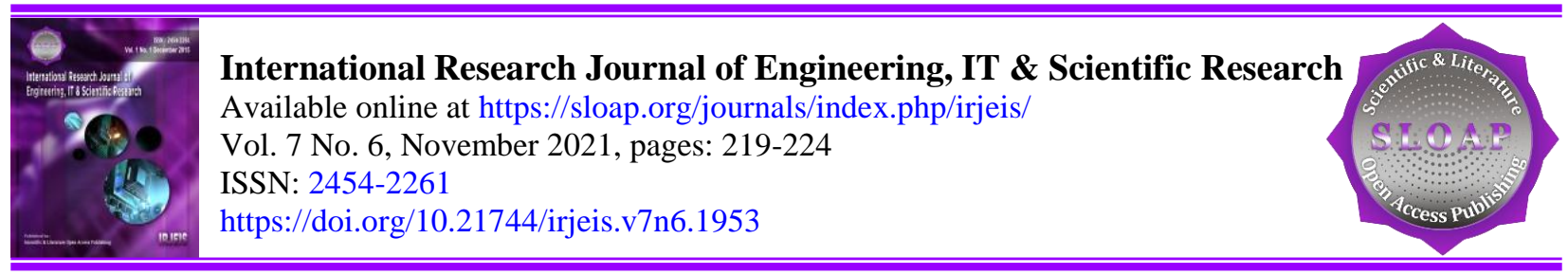

\title{
General Radiographic Patient Dose Monitoring Using Conformity Test Data
}

Article history:

Submitted: 27 August 2021

Revised: 09 Sept 2021

Accepted: 18 Oct 2021

\section{Keywords:}

conformity test data;

dosage monitoring;

entrance surface air kerma

(ESAK);

entrance surface dose (ESD);

radiographic;

$X$-ray;

\begin{abstract}
Currently, the Nuclear Energy Supervisory Agency (BAPETEN) is actively guiding users or license holders related to patient protection against radiation hazards or often referred to as radiation protection and safety on medical exposure. Protection against medical exposure became a big issue when the mandatory compliance test on X-ray equipment for diagnostic and interventional radiology was introduced. In addition, license holders through their medical practitioners are also required to use the level of medical exposure guidelines. While PERKA BAPETEN No. 9, 2011 concerning the Suitability Test of Diagnostic and Interventional Radiology X-Ray device, states that one of the test parameters that directly affect the patient's radiation dose and determine the feasibility of operating the X-Ray device to the patient is information on the dose or rate of radiation dose received by the patient. Monitoring doses with Entrance Surface Air Kerma (ESAK) or what is often referred to as ESD (entrance surface dose) using suitability conformity test data starting from 50,60,70,80,90 and $100 \mathrm{kVp}$ with $20 \mathrm{mAs}$ at SID 100 meters. The results of the research on the value of ESAK was $0.049 \mathrm{mGy}$, an ESAK value that still met the national I-DRL value from BAPETEN Regulation No. 1211/K/V/2021.
\end{abstract}

International research journal of engineering, IT \& scientific research (C) 2021. This is an open access article under the CC BY-NC-ND license (https://creativecommons.org/licenses/by-nc-nd/4.0/).

\section{Corresponding author:}

I Ketut Putra,

Physics Faculty of Mathematics and Natural Sciences Udayana University, Denpasar, Indonesia.

Email address: putra_jongrang@roketmail.com

a Physics Faculty of Mathematics and Natural Sciences Udayana University, Denpasar, Indonesia

b Physics Faculty of Mathematics and Natural Sciences Udayana University, Denpasar, Indonesia

c Physics Faculty of Mathematics and Natural Sciences Udayana University, Denpasar, Indonesia 


\section{Introduction}

The X-ray machine is a device used to perform medical diagnoses using X-rays. The beam emitted from the tube is directed at the body part to be diagnosed. The X-ray beam will penetrate the body part and will be captured by the film so that an image will be formed of the irradiated body part (Sutapa et al., 2018; Wilks, 1987). Before operating the X-ray machine, it is necessary to set the parameters to get the desired X-ray. These parameters are voltage $(\mathrm{kV})$, tube current (mA), and exposure time (s) (Adler et al., 1992; Akhadi, 2000). Tube voltage on X-ray equipment is one of the factors that can be controlled to reduce scattered radiation and reduce the patient's dose of radiation hazards or in the regulatory language is radiation protection and safety in medical exposure used in radiodiagnosis (Vassileva, 2004). Protection against medical exposure became a big issue when the mandatory compliance test on X-ray equipment for diagnostic and interventional radiology was introduced (Sikumbang, 2018; Susilo \& Setiowati, 2012). In addition, licensees through their medical practitioners are also required to use the level of medical exposure guidelines when performing diagnostic and interventional radiology procedures. In PP No. 33, 2007 Articles 39 and 40 stipulate that medical practitioners are required to use medical exposure guidelines to optimize patient protection and to ensure that medical exposure guidelines are complied with (Horner \& Devlin, 1998; Sherrick et al., 1994). The Guidance Level is the guiding value that should be achieved through the implementation of medical activities with tested methods. Guidance values for diagnostic radiology activities are expressed in dose values or dose rates. While PERKA BAPETEN No. 9 of 2011 concerning the Suitability Test of Diagnostic and Interventional Radiology $\mathrm{X}$-Ray device, states that one of the test parameters that directly affect the patient's radiation dose and determine the feasibility of operating the X-Ray device to the patient is information on the dose or rate of radiation dose received by the patient (Suryatika et al., 2019; Putra et al., 2020).

\section{Research Methods}

The research was conducted at the Radiology Unit of the Kasih Ibu Hospital Kedonganan. Meanwhile, data analysis was carried out at the Biophysics and Medical Physics Laboratory at Bukit Jimbaran Campus. The tools used in this study were X-ray aircraft, CR (Computer Radiography), Lux meter, Humidity meter, thermometer, patient medical records, and conformity test data (Yoo et al., 2013; Ribeiro \& Yoshimura, 2008). Patient identification information that is needed other than age group is gender and weight. Each type of examination requires data of at least 10 patients for each type of examination that is infrequent or infrequent and 20 patients for each type of examination that is frequent or multiple (Suandayani et al., 2020). If the facility can estimate the patient's workload per type of examination for each modality, then the number of patient samples required is at least $30 \%$ of the workload. In this research, an X-ray machine was used with voltage variations ranging from 50,60,70,80, 90, and $100 \mathrm{kVp}$, the tube current was set to $200 \mathrm{~mA}$ and the SID was $100 \mathrm{~cm}$. Medical record data were taken for thorax examination because this examination most often occurs in radiology units and conformity test data (Rusmanto, 2016).

\section{Results and Discussions}

The research data used is the conformity test data for X-ray device Kasih Ibu Hospital, Kedonganan, Badung, Bali. Information on radiation output dose data such as field area $20 \mathrm{~cm} \times 20 \mathrm{~cm}$, tube current $200 \mathrm{~mA}$, setting time $0.1 \mathrm{~s}$, SID 100, and average patient thickness (tp) for PA projection of $23 \mathrm{~cm}$ (Costa \& Pelegrino, 2014; Porto et al., 2014). With the test data for the suitability of the X-ray tube voltage, it is possible to determine the dose in Gy and the radiation output in $\mathrm{Gy} / \mathrm{mAs}$ which is exemplified as follows:

$$
D(m R)=\frac{P m A s(k V)^{2}}{r^{2}}
$$

Where:

$\mathrm{D} \quad$ : Exposure dose in $\mathrm{mR}$

$\mathrm{P} \quad$ : X-ray machine factor $(\mathrm{P}=15)$

$\mathrm{mA}: \mathrm{X}$-ray tube current

$\mathrm{kV}: \mathrm{X}$-ray tube voltage 
$\mathrm{r} \quad$ : SID, distance from source to detector in $\mathrm{cm}$

For a voltage that is set to $50 \mathrm{kV}$ and the measured voltage is $48.90 \mathrm{kV}$, the exposure dose can be determined as follows:

$$
\begin{aligned}
D(m R) & =\frac{15 \times 20(48,90)^{2}}{100^{2}} \\
& =74,6 \mathrm{mR}
\end{aligned}
$$

Next, the unit conversion is carried out from the dose in $\mathrm{mR}$ to the dose in Gy as shown below:

$$
\begin{aligned}
& 1 \mathrm{mR}=10^{-3} R, \quad \text { where } 1 R=0,87 \mathrm{rad} \\
& =10^{-3} \times 0,87 \mathrm{rad}, \text { where } 1 \mathrm{rad}=10^{-2} \mathrm{~Gy} \\
& =0,87 \times 10^{-5} \mathrm{~Gy} \\
& =87 \mu \mathrm{Gy}
\end{aligned}
$$

So that:

$$
\begin{aligned}
74,6 m R & =74,6 \times 87 \mu G y \\
& =6490 \mu G y
\end{aligned}
$$

And the radiation output is $6490 \mathrm{~Gy} / 20 \mathrm{mAs}=324.5 \mathrm{~Gy} / \mathrm{mAs}$, other data can be shown in Table 1.

Table 1

X-Ray tube voltage conformity test data

\begin{tabular}{ccccccc}
\hline No. & $\mathrm{kV}$ seting & $\mathrm{kV}$ measured & $\%$ Eror & $\mathrm{mAs}$ & Dose $(\mu \mathrm{Gy})$ & Radiation output $(\mu \mathrm{Gy} / \mathrm{mAs})$ \\
\hline 1 & 50 & 48,90 & $2,20 \%$ & 20 & 6490 & 324,5 \\
2 & 60 & 59,25 & $1,25 \%$ & 20 & 8810 & 440,5 \\
3 & 70 & 67,98 & $2,89 \%$ & 20 & 10360 & 518,0 \\
4 & 80 & 77,68 & $2,90 \%$ & 20 & 11970 & 598,5 \\
5 & 90 & 85,82 & $4,64 \%$ & 20 & 13890 & 694,5 \\
6 & 100 & 98,80 & $1,20 \%$ & 20 & 16010 & 800,5 \\
\hline
\end{tabular}

Where the percentage error (\% error) can be determined using the following equation:

$$
\% \text { Eror }=\left[\frac{\text { Setting voltage }- \text { Measured voltage }}{\text { Seting voltage }}\right] \times 100 \%
$$

Putra, I. K., Ratnawati, G. A. A., \& Sutapa, G. N. (2021). General radiographic patient dose monitoring using conformity test data. International Research Journal of Engineering, IT \& Scientific Research, 7(6), 219-224. https://doi.org/10.21744/irjeis.v7n6.1953 
Referencing the graph from Table 1 can be shown in the following Figure:

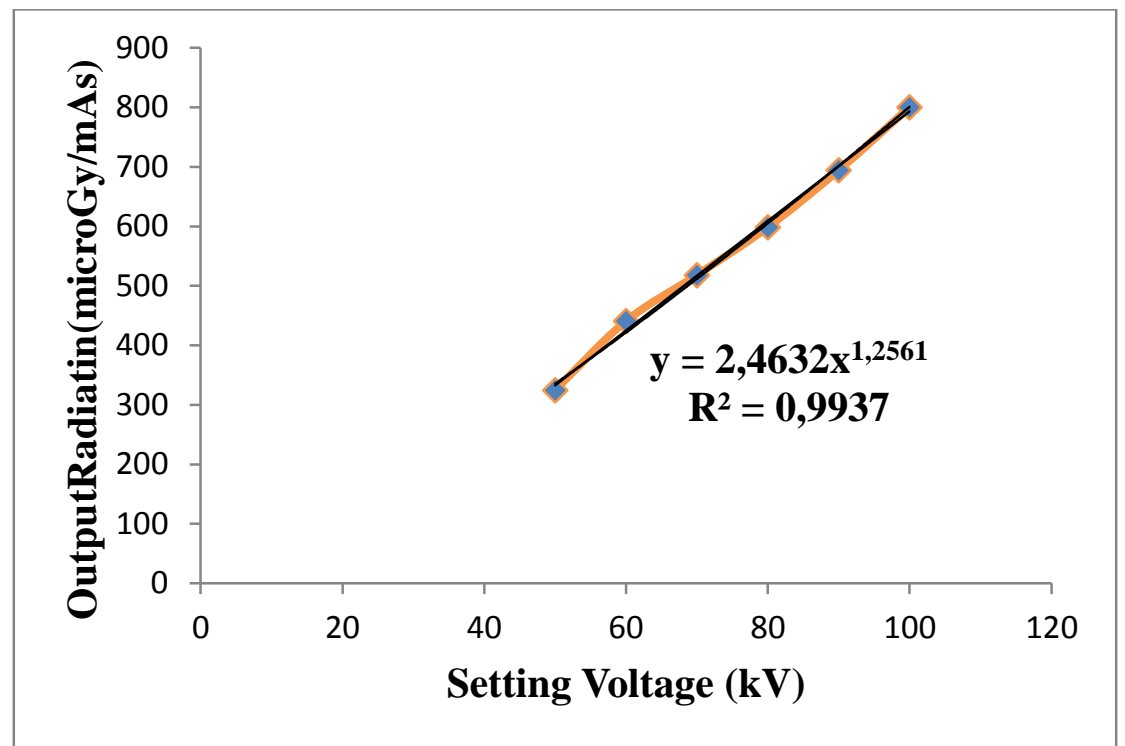

Figure 1 Graph of X-ray tube voltage accuracy conformity test

The quadratic line equation obtained in Figure 1 is the INAK value of the equation:

$$
\begin{aligned}
E S A K & =I N A K \times\left(\frac{100}{F S D}\right)^{2} \times m A s \\
& =2,084 k V^{1,2845} \times\left(\frac{100}{F S D}\right)^{2} \times m A s
\end{aligned}
$$

Where:

$$
\begin{aligned}
& \text { FSD }: \text { FFD }-\mathrm{tp}-\mathrm{d} \\
& \text { FFD }: \text { Focus distance to film }=130 \mathrm{~cm} \\
& \mathrm{~d} \quad: \text { Distance between detector and holder detector }=5 \mathrm{~cm} \\
& \text { FSD }: 130 \mathrm{~cm}-25 \mathrm{~cm}-5 \mathrm{~cm}=102 \mathrm{~cm}
\end{aligned}
$$

Thus, ESAK can be calculated as follows:

$$
\begin{aligned}
E S A K & =(2,084)^{1,2845} \times\left(\frac{100}{102}\right)^{2} \times 20 \\
& =49,357 \mu G y=0,049 \mathrm{mG} y
\end{aligned}
$$

The ESAK value can be used to determine the amount of exposure dose which refers to the national I-DRL value, as stated in the Decree of the Head of BAPETEN No. 1211/K/V/2021 concerning the Determination of Indonesian Diagnostic Reference Level Values for X-ray Ct Scan and General Radiography Modalities (Ratnawati et al., 2019; Winkler, 1976). Where in this decision the ESAK value for Chast PA is $0.4 \mathrm{mGy}$, so the ESAK value in this study still meets the national I-DRL value (Proost \& Meijer, 1992; Bonello et al., 2009). The method of implementation and the results of this study are following the statement that patient dose information can be estimated if each diagnostic X-ray machine has 2 important components, namely radiation output data and irradiation recordings containing information on technical parameters, which was conveyed, in Implementation Level Guide to Medical Exposure and X-Ray Aircraft Suitability Tests Related to Dosage Information or Radiation Dose Rates Received by Patients. From this local DRL value, it can be implemented by one way of pasting the radiation output data near the Radiology operator room at the Sanjiwani Gianyar General Hospital and can be used within the next 1-2 years (Susanto, 2018). 


\section{Conclusion}

The conclusion of this study is that dose monitoring with ESAK or often referred to as ESD using conformity test data has been determined to be $0.049 \mathrm{mGy}$, which is the local DRL value of the Sanjiwani General Hospital Gianyar and according to the national I-DRL value from BAPETEN Regulation No. 1211/K/V/2021 (Gabbert et al., 2007; de Oliveira \& Lourenço, 2021).

Conflict of interest statement

The authors declared that they have no competing interests.

Statement of authorship

The authors have a responsibility for the conception and design of the study. The authors have approved the final article.

Acknowledgments

$\mathrm{I} \mathrm{am} / \mathrm{We}$ are grateful to two anonymous reviewers for their valuable comments on the earlier version of this paper. Acknowledgments to Udayana University for funding the implementation of this research through the Unud DIPA PNBP in the fiscal year 2021 following the Letter of Appointment for the Study Program Leading Research (PUPS).

Putra, I. K., Ratnawati, G. A. A., \& Sutapa, G. N. (2021). General radiographic patient dose monitoring using conformity test data. International Research Journal of Engineering, IT \& Scientific Research, 7(6), 219-224. https://doi.org/10.21744/irjeis.v7n6.1953 


\section{References}

Adler, A., Carlton, R., \& Wold, B. (1992). A comparison of student radiographic reject rates. Radiologic technology, 64(1), 26-32.

Akhadi, M. (2000). Basics of Radiation Protection. Jakarta: Rineka Reserved.

Bonello, L., Camoin-Jau, L., Armero, S., Com, O., Arques, S., Burignat-Bonello, C., ... \& Paganelli, F. (2009). Tailored clopidogrel loading dose according to platelet reactivity monitoring to prevent acute and subacute stent thrombosis. The American journal of cardiology, 103(1), 5-10. https://doi.org/10.1016/j.amjcard.2008.08.048

Costa, A. M., \& Pelegrino, M. S. (2014). Evaluation of entrance surface air kerma from exposure index in computed radiography. Radiation Physics and Chemistry, 104, 198-200. https://doi.org/10.1016/j.radphyschem.2014.05.005

de Oliveira, E. C., \& Lourenço, F. R. (2021). Data reconciliation applied to the conformity assessment of fuel products. Fuel, 300, 120936. https://doi.org/10.1016/j.fuel.2021.120936

Gabbert, F., Memon, A., \& Wright, D. B. (2007). I saw it for longer than you: The relationship between perceived encoding duration and memory conformity. Acta psychologica, 124(3), 319-331. https://doi.org/10.1016/j.actpsy.2006.03.009

Horner, K., \& Devlin, H. (1998). The relationship between mandibular bone mineral density and panoramic radiographic measurements. Journal of dentistry, 26(4), 337-343. https://doi.org/10.1016/S0300-5712(97)000201

Porto, L., Lunelli, N., Paschuk, S., Oliveira, A., Ferreira, J. L., Schelin, H., ... \& Khoury, H. (2014). Evaluation of entrance surface air kerma in pediatric chest radiography. Radiation Physics and Chemistry, 104, 252-259. https://doi.org/10.1016/j.radphyschem.2014.02.014

Proost, J. H., \& Meijer, D. K. (1992). MW/Pharm, an integrated software package for drug dosage regimen calculation and therapeutic drug monitoring. Computers in biology and medicine, 22(3), 155-163. https://doi.org/10.1016/0010-4825(92)90011-B

Putra, I. K. ., Ratnawati, G. A. A. ., \& Sutapa, G. N. . (2020). Monitoring of patients using radiodiagnostic dosage EI (Exposure Index) on CR (Computed Radiography). International Research Journal of Engineering, IT \& Scientific Research, 6(6), 45-49.

Ratnawati, I. G. A. A., Suandayani, N. K. T., \& Sutapa, G. N. (2019). The Linearity of X-ray Devices Radiation Output and Its Relationship with Patient Thickness. International Journal of Physical Sciences and Engineering, 3(3), 1-6.

Ribeiro, L. A., \& Yoshimura, E. M. (2008). Entrance surface dose measurements in pediatric radiological examinations. Radiation measurements, 43(2-6), 972-976. https://doi.org/10.1016/j.radmeas.2007.11.059

Rusmanto, T. (2016). Do audit firm size and their services matter on auditor independence: A Case of Indonesia. Journal of Business Studies Quarterly, 7(3), 1.

Sherrick, A. D., Brown, L. R., Harms, G. F., \& Myers, J. L. (1994). The radiographic findings of fibrosing mediastinitis. Chest, 106(2), 484-489. https://doi.org/10.1378/chest.106.2.484

Sikumbang, A. S. (2018). Analysis of Radiation Doses on Mobile X-rays of Emergency Patients in the ICU Room. University of North Sumatra, Medan.

Suandayani, N. K. T., Sutapa, G. N., \& Kasmawan, I. G. A. (2020). Quality control of X-rays with collimator and the beam alignment test tool. International Journal of Physical Sciences and Engineering, 4(3), 7-15.

Suryatika, I. B. M., Sutapa, G. N., \& Kasmawan, I. G. A. (2019). Radiology patient dosage monitoring for local diagnostic reference level. International Research Journal of Engineering, IT \& Scientific Research, 5(5), $26-31$.

Susilo, S., \& Setiowati, L. (2012). Application of Digital Radiography Tools in Photorontgen Service Development. Journal of Mathematics and Natural Sciences, State University of Semarang, 35(2), 145-150.

Sutapa, G. N., Yuliara, I. M., \& Ratini, N. N. (2018). Verification of dosage and radiation delivery time breast cancer (Mammae Ca) with ISIS TPS. International journal of health sciences, 2(2), 78-88.

Vassileva, S. (2004). Bullous systemic lupus erythematosus. Clinics in dermatology, 22(2), 129-138.

Wilks, R. J. (1987). Principles of radiological physics. Churchill Livingstone.

Winkler, N. T. (1976, March). Quality control in diagnostic radiology. In Application of Optical Instrumentation in Medicine IV (Vol. 70, pp. 125-131). International Society for Optics and Photonics.

Yoo, W. J., Jeon, D., Seo, J. K., Shin, S. H., Han, K. T., Youn, W. S., ... \& Lee, B. (2013). Development of a scintillating fiber-optic dosimeter for measuring the entrance surface dose in diagnostic radiology. Radiation measurements, 48, 29-34. https://doi.org/10.1016/j.radmeas.2012.11.001 